\title{
HAND2 Gene
}

National Cancer Institute

\section{Source}

National Cancer Institute. HAND2 Gene. NCI Thesaurus. Code C102790.

This gene plays a role in both transcriptional regulation and cardiac development. 